\title{
ROLE OF BRAND PERSONALITY TRAITS IN CREATING AN UMBRELLA BRAND FOR SMALL-SCALE SPORTS EVENTS: THE CASE OF GORSKI KOTAR, CROATIA
}

Marko PERIĆ, Ana ČUIĆ TANKOVIĆ, Jelena ĐURKIN

Faculty of Tourism and Hospitality Management, Opatija

UDK: $338.48-5(497.561): 796$ 659.12:338.48

Izvorni znanstveni rad

Primljeno: 8. 9. 2016.

While the importance and positive impact of small-scale sports events for the tourism of host regions has been well researched, the possibilities of branding such events under a common denominator have not been fully explored. This paper attempts to provide an approach for using the concepts of brand personality and umbrella brand for the purpose of small-scale sports event analysis and promotion recommendations. Gorski Kotar, an underdeveloped region in Croatia, was chosen as the research area. The research target was small-scale sports events organised in this area. The aim was to build a general recommendation of an overall umbrella brand for all examined events, developed from the brand personality traits of each event (sub-brands). Using desk research along with workshops and interviews with organisers, three characteristics for each of the 81 small-scale sports events were extracted. The existing framework of five brand-personality dimensions by Aaker (1997) was used for the purpose of coding characteristics into traits and later linking with factors. An overall brand personality profile of all events was created and results imply the necessity of introducing a new factor called Nature (nature-oriented) into the existing framework.

Keywords: brand personality, umbrella brand, small-scale sports events, tourism

$\triangle \quad$ Marko Perić, Faculty of Tourism and Hospitality Management, University of Rijeka, Primorska 42, P.O.B. 97, 51410 Opatija, Croatia. 
Belonging to the group of so-called new states (post-1989) and being one of the independent countries created after the dissolution of Yugoslavia, Croatia has developed significantly in the past 25 years. Regarding tourism, after a "lost decade" in the 1990s (due to the war between former Yugoslav countries), Croatia started a significant recovery, in terms of renovating and promoting its tourist facilities and tourist destinations in the new millennium. In 2015, tourism revenue amounted to almost 8 billion euro, accounting for 18.1\% of GDP (Ministry of Tourism, 2016a). Also, in recent years the number of tourists and overnights in Croatia has exceeded the numbers recorded in the most successful pre-war years (1987/88), but many problems still characterise the industry. Croatia is an example of a mature tourist destination that is dominated by a few products ("the sun and the sea", nautical tourism, business tourism and cultural tourism) with a highly seasonal business period (Ministry of Tourism, 2015). Since there is insufficient differentiation and lack of innovative and high-quality products and services for visitors, there are few reasons to travel to or visit Croatia outside the high summer season. However, national tourism authorities have recognised these undesirable characteristics and have stipulated that the vision for tourism development by 2020 should be based, among other things, on the principles of "beyond the sun and the sea" and "tourism across the country" (Government of the Republic of Croatia, 2013). This means it is necessary to develop and commercialise a new, internationally competitive system of activities that has the highest chances of success with regard to an area's existing and potential resources and attractions. For instance, cycling tourism, adventure and sports tourism, health tourism, eco-tourism, and rural and mountain tourism have been identified as products with visible growth potential (Government of the Republic of Croatia, 2013). What's more, diversity and preserved environment are among the key identity and value characteristics of the central identity of Croatia's branding. These guidelines provide less-developed continental destinations the opportunity to use their resources in designing and branding new tourism products and services.

Gorski Kotar is an example of such a less-developed continental mountain destination in Croatia. It is a part of Primorje-Gorski Kotar (PGK) County, one of the most developed counties in Croatia. PGK County accounted for $18.2 \%$ of the total 71.6 million overnights in Croatia in 2015 (Ministry of Tourism, 2016b) and its tourism relies heavily on "the sun and the sea" product. However, because of its geographical position, Gorski Kotar cannot count on this predominant product. Ac- 
DRUŠ. ISTRAŽ. ZAGREB GOD. 26 (2017), BR. 4 STR. 561-581

PERIĆ, M., ČUIĆ TANKOVIĆ, A., ĐURKIN, J. ROLE OF BRAND... counting for only a modest share of about $1 \%$ of the County's accommodation capacity, arrivals and overnights in recent years, Gorski Kotar is not "visible" enough under the auspices of PGK County. The challenges involved in branding Gorski Kotar, a wooded and mostly rural region, as a tourist destination include the creation of a distinctive and innovative brand concept, attractive to the national as well as international market. A previously conducted analysis of the potential of Gorski Kotar (Perić, Škorić, \& Jurčević, 2016) revealed that the region has a significant number and variety of existing small-scale sports events that could be improved to ensure greater appeal for participants and visitors, but which require prior branding for the purpose of joint promotion. The concept of umbrella branding using the emergent brand personality of existing small-scale tourist events could be helpful in developing an innovative approach to a specific tourism product.

The aim of this paper is to create a proposal for an umbrella brand for the existing small-scale sports events of Gorski Kotar, based on key common characteristics categorised using personality brand analysis. Since no previous research has used brand personality for creating an umbrella brand, this paper presents an innovative inductive methodology approach to unify the small-scale sports events and opens up new lines of research not just in the field of marketing, but also within management studies because of important umbrella brand implementation possibilities for event organisers.

The first section of this paper provides a brief literature overview of small-scale sports events as a specific part of the tourism offering and an overview of the concepts of brand, umbrella brand and brand personality. The second section describes the methodology and provides regional context, while the third section details and discusses the results obtained and provides some recommendations for sport event organisers in Gorski Kotar. The paper finishes with concluding remarks, limitations and future research recommendations.

\section{LITERATURE REVIEW}

\section{Tourism and small-scale sports events}

Active or passive participation in sports is a frequent motivation for travelling to tourist destinations. It provides a good foundation for the development of sports tourism and much attention has been given to this phenomenon (Buning \& Gibson, 2015; Cho, Ramshaw, \& Norman, 2014; De Knop \& Van Hoecke, 2003; Downward, 2005; Gozalova, Shchikanov, Vernigor, \& Bagdasarian, 2014; Roche, Spake, \& Joseph, 2013; Weed \& Bull, 2009). Most often, sports tourism is defined as 
DRUŠ. ISTRAŽ. ZAGREB GOD. 26 (2017), BR. 4, STR. 561-581

PERIĆ, M., ČUIĆ TANKOVIĆ, A., ĐURKIN, J.: ROLE OF BRAND.. specific travel outside the customer's usual environment for either passive or active involvement in sport where sport is the prime motivational reason for travel (World Tourism Organization, 2010). However, following a wider approach established by the British Tourist Authority (1981) and Standeven and Tomlinson (1994), sport trips and day visits could also be treated as a part of sports tourism (Perić, 2015; Weed \& Bull, 2009).

Certainly, sports tourism is multi-faceted and exists under a variety of forms and names (see Bartoluci, 1995; Gammon \& Robinson, 1997; Gibson, 1998; Glyptis, 1982; Weed \& Bull, 2009), based on whether sport is the primary or secondary motive for travel, and whether the aim is to participate as an active or passive participant. Put simply, participants travel to take part in sports, to watch sports, and to visit sports-related attractions (e.g. famous stadiums, halls of fame). In his meta-review of sports tourism research, Weed (2009) stated that event tourism is probably the most widely researched area that obviously overlaps with sports tourism. Indeed, taking part or watching sports or visiting attractions are clearly related to sports events and people often plan holidays around the world based on a sport event (Ratten, 2011). Weed (2009) actually concluded that "event sports tourism is the highest profile product within sports tourism" (p. 621). Whereas Gibson (1998) equates events with spectating, according to Weed and Bull (2009) event sports tourism involves both active participants (competitors) and spectators, although visitor types may vary, as some sports events are more spectator-driven than others (Gozalova et al., 2014).

There are many types of sports events and destinations which feature a number of sports facilities that make growing efforts to bid for sports events of different sizes. As a unique combination of people and activities within a particular spatial-temporal dimension (Getz, 2008; Weed \& Bull, 2009), sports events can be part of a tourism product portfolio generating many implications. Sports events that attract business and residents in the area may be an impetus for increased trade and revenue, addressing seasonal fluctuations, and destination image creations or improvements (Chalip, 2004; Cheung, Mak, \& Dixon, 2016; Dixon, Henry, \& Martinez, 2013; Getz, 2008; Khodr, 2012; O'Brien, 2007; Smith, 2006). Since larger international events, sometimes called mega events or hallmark events, seem to possess higher attractiveness than small-scale events, scholars have put more effort in examining large events while neglecting small-scale events. According to Higham (1999), small-scale sports events refer to regularly occurring sports contests, domestic competitions, and/or international sports competitions with a smaller global appeal. They are general- 
DRUŠ. ISTRAŽ. ZAGREB GOD. 26 (2017), BR. 4, STR. 561-581

PERIĆ, M., ČUIĆ TANKOVIĆ, A., ĐURKIN, J. ROLE OF BRAND... ly smaller in size, scale, scope and reach than their larger counterparts. Small-scale sports events typically operate within existing infrastructures and necessitate minimal investments of public funds, while crowding and infrastructural congestion are less likely (Higham, 1999). Therefore, if managed properly, regular small-scale sports events may have more positive impacts for communities and destinations than one-off major events (Gibson, Kaplanidou, \& Kang, 2012; Gibson, Willming, \& Holdnak, 2003; Higham, 1999).

These characteristics of small-scale sports events are recognised widely and destinations are making additional efforts to attract such events. Despite the fact that sports events of all sizes are important for promoting a positive destination image (Hallmann \& Breuer, 2011; Smith, 2006; Weed, 2009), the image and the brand of the sport event itself are also important. Small-scale sports events held throughout the year can be grouped to facilitate the implementation of joint event strategies and achieve a synergic effect. This event portfolio approach (Chalip, 2004; Jago, Chalip, Brown, Mules, \& Ali, 2003; Pereira, Mascarenhas, Flores, \& Pires, 2015; Ziakas, 2014) requires a joint branding strategy to create a distinctive product.

Sport event organisers need to be aware of the factors that influence the brand creation process. Although researchers have identified numerous benefits associated with sport brands, insufficient attention has been devoted to brand builders (Ulrich \& Smallwood, 2007), especially in a sport-event tourism context. Parent and Séguin (2008) studied brand creation for one-off international sports events, distinguishing the internal and external stakeholder communication paths on the case of MONTREAL 2005. They also analysed the brand creation and its related factors, where the leadership group was the most important aspect for brand creation. Parent, Eskerud, and Hanstad (2012) researched the branding process of smaller international recurring sports events, testing the model for brand creation of one-off large-scale recurring sports events. Both studies deal with branding of solely one international event in developed countries, but there is a lack of research on the umbrella brand creation process for small-scale sports events in less-developed areas.

\section{Brand, umbrella brand and brand personality}

A brand is defined as "a name, term, sign, symbol or design, or a combination of them" (Keller, 1993), used to identify a product or service and distinguish it from the competition (Bergh \& Katz, 1999), and to establish a competitive advantage (Kotler \& Keller, 2006). A strong brand can have a positive differential marketing effect, because it attracts more favourable attributes and overall preferences, so customers can react in a 
DRUŠ. ISTRAŽ. ZAGREB GOD. 26 (2017), BR. 4, STR. 561-581

PERIĆ, M., ČUIĆ TANKOVIĆ, A., ĐURKIN, J. ROLE OF BRAND.. more positive way (Hoeffler \& Keller, 2003). According to Keller (2003), broad criteria are used for choosing and designing brand elements: memorability, meaningfulness, aesthetic appeal, transferability, adaptability and flexibility over time, and legal and competitive protectability and defensibility. The characteristic of transferability is considered both within and across product categories through elements of awareness, attributes, benefits, images, thoughts, feelings, attitudes and experiences (Keller, 2003; Singh, 2013).

Brand personality is the set of human characteristics associated with a brand (Aaker, 1997) and represents the basis for the customer-brand relationship because it assures the connection between emotional brand benefits (Aaker, 1996). Azoulay and Kapferer (2003) give a stricter definition: "Brand personality is the set of human personality traits that are both applicable to and relevant for brands". According to the self-congruity theory, people are more likely to purchase or recommend brands whose personality traits match their own self-concept (Usakli \& Baloglu, 2011). Brand personality provides a connection between the brand's emotional and self-expressive benefits, where success depends on the extent to which the brand interacts with the target audience on the emotional and rational level (De Chernatony, 2009), providing an element of differentiation when product attributes are very similar for competing brands.

According to Aaker (1997), brand personality is multidimensional and consists of five dimensions: sincerity, excitement, competence, sophistication and ruggedness. Sincerity has attributes such as down-to-earth, real, sincere and honest. Excitement is represented by the following traits: daring, exciting, imaginative and contemporary. Competence is illustrated by attributes like intelligent, reliable, secure and confident. Sophistication is characterised by traits such as glamorous, upper class, charming and feminine while ruggedness has attributes such as outdoorsy, masculine, tough and rugged. Various authors have tested brand personality dimensions in Japan and Spain (Aaker, Benet-Martinez, \& Garolera, 2001), and in Russia (Supphellen \& Grønhaug, 2003), with the overall conclusion that the Aaker (1997) brand personality scale is cross-culturally robust, proving that it remains "the most stable, reliable, and comprehensive measure to gauge brand/ product personality" (Hosany, Ekinci, \& Uysal, 2006).

Brand personality has been adapted from product categories and applied to tourist destinations where it is central to destination branding (Morgan, Pritchard, \& Pride, 2004; Murphy, Moscardo, \& Beckendorff, 2007). Various authors have focused on brand personality in the sphere of marketing and 
DRUŠ. ISTRAŽ. ZAGREB GOD. 26 (2017), BR. 4 STR. 561-581

PERIĆ, M., ČUIĆ TANKOVIĆ, A., ĐURKIN, J. ROLE OF BRAND... sports management (Azoulay \& Kapferer, 2003; Braunstein \& Ross, 2010; Carlson \& Donovan, 2013; Heere, 2010; Lee \& Cho, 2009). Azoulay and Kapferer (2003) have challenged the conceptual validity of Aaker's brand personality scale analysing the definition of brand personality and the comparison of personality traits to elements of the five-factor model in psychology. Lee and Cho (2009) measured five dimensions of sport event personality in the context of sponsorship. Starting from Aaker's (1997) personality traits and implying the importance of sporting events as a promotional communication tool, they developed personality dimensions for sponsoring brands of sponsoring events: diligence, uninhibitedness, fit, tradition and amusement. Braunstein and Ross (2010) re-examined the general brand personality dimensions with regard to the unique sphere of sport, but their model did not produce dimensions that demonstrated discriminant validity. They tested their adapted scale for brand personality created from Aaker's instrument for use in sport, and the final survey instrument included a total of 84 descriptor items with these factors: Success, Sophistication, Sincerity, Rugged, Community-driven and Classic. Čáslavová and Petráčková (2011) evaluated the results for particular brands of big sports events according to Aaker's basic five factors. They described each brand (FIFA World Cup, Tour de France, Olympic Summer Games) by all the five brand personality dimensions and they provided the results for each event separately. The importance of their research is in the usage of the brand personality for forming a communication strategy for mega sports events. However, no research yet applied the brand personality traits on small-scale sports events, nor were they used for creating an umbrella brand.

The umbrella brand can be characterised by the concept of brand architecture showing a hierarchical level of brand with different strategies for multiple targets group (Braun \& Zenker, 2010). It can be used with two strategies, the first relatively liberal towards products and subsidiaries, the other exercising real control (Kapferer, 2012). A larger product portfolio with a well-established umbrella brand helps an organisation strengthen its brand positioning and increase its marketing efficiency (Liu \& Hu, 2011). The architecture of a brand can be managed by a double level, including mother brands and daughter brands, where each daughter brand is named descriptively, and thus represents a statement of the brand's values, collecting benefit of all products under the umbrella brand (Kapferer, 2012). In the literature, different views have been proposed about the impacts of adding products under the same umbrella brand: the increased size may serve as a positive 
DRUŠ. ISTRAŽ. ZAGREB GOD. 26 (2017), BR. 4, STR. 561-581

PERIĆ, M., ČUIĆ TANKOVIĆ, A., ĐURKIN, J.: ROLE OF BRAND...

\section{METHODOLOGY}

To provide context for the choice of methodology and interpretation of results, Gorski Kotar, the research region chosen, is described in detail. This is followed by a description of the qualitative methodology used for this research.

\section{Regional context}

Gorski Kotar, a wooded mountainous area in PGK County, is one of the most protected areas in Croatia, with Risnjak National Park covering most of the region. It is divided between three towns and six municipalities. It should be noted that according to geographical and natural characteristics, two neighbouring areas, Platak and Bjelolasica also belong to Gorski Kotar. Because of the region's favourable geo-strategic position, one of Europe's most important routes passes through Gorski Kotar, linking Central Europe with the Adriatic Sea. It therefore has good traffic links with three nearby major towns, Rijeka, Zagreb and Karlovac. Other important infrastructure, such as railways, storage lakes, oil pipelines, etc., are also located in Gorski Kotar. Vast forests and an abundance of water are the reason that forestry and wood processing were established as the traditionally major economic activities. However, in the last twenty years many firms have gone bankrupt and young educated people are leaving the region. Today, with only 23,011 inhabitants in an area of 1,275.05 $\mathrm{km}^{2}$, the whole region is suffering from depopulation.

In terms of tourism, Gorski Kotar is still underdeveloped. Although tourism has existed in the region for a long time and each town and municipality has established a local tourism board, results are not satisfactory. A share of only $1 \%$ of the total PGK County accommodation capacity $(1,616$ beds, of which only 120 in hotels), $1.16 \%$ of arrivals $(28,607)$, and $0.6 \%$ of overnights $(80,754)$ in 2015 confirms the fact that Gorski Kotar is not sufficiently distinctive on the tourist market. This 
DRUŠ. ISTRAŽ. ZAGREB GOD. 26 (2017), BR. 4 STR. 561-581

PERIĆ, M., ČUIĆ TANKOVIĆ, A., ĐURKIN, J. ROLE OF BRAND... is not a new problem and all recent strategies (FTHM, 2012; FTHM, 2013; Government of the Republic of Croatia, 2013) have highlighted the need to distinguish Gorski Kotar from the coastal area of PGK County. The most important tourism products of Gorski Kotar are nature-based and include activities such as sports tourism (mountaineering and hiking, cycling, sport fishing, skiing, and other winter/snow activities), health tourism, rural tourism, eco-tourism and gastro tourism. Natural resources in combination with a typically mountainous climate, a long tradition of local sports clubs and associations (especially in winter sports), and a network of local sport facilities (e.g. cycling and hiking trails, ski and sledding slopes, Nordic and biathlon centres) enable many outdoor sport and recreational activities during the year. These are certainly the reasons why sports events are among the most numerous events in Gorski Kotar (see Perić et al., 2016, and the official site of Gorski Kotar for a calendar of events: http://www.gorskikotar.hr).

\section{Qualitative research}

The research design consisted of two steps. In the first step, the idea was to identify the number and type of sports events organised in Gorski Kotar and to establish their key characteristics (three per each event). In order to identify the number and characteristics of these events, desk research on web sources related to Gorski Kotar and its tourist offering were conducted. The official websites of local tourism organisations, sports associations and private companies as event organisers were chosen as key sources. Lundmark and Muller (2010) implemented a similar approach in their survey of the supply of nature-based tourism activities in Sweden. A justification for this approach is the growing importance of the Internet in the tourist's search for information and bookings (Buhalis \& Laws, 2001). Data was gathered from the area of Gorski Kotar (nine administrative units), but also from two geographically adjacent areas: Platak and Bjelolasica. This stage of research lasted from June 2015 to January 2016 and two problems occurred: an insufficient number of available websites (only one third of 101 sports clubs and associations in Gorski Kotar have an active website) and the poor quality of information on some events presented via the Internet (many websites provide only scanty information about an event, mostly just its date and venue). Therefore, additional activities focused on gathering primary data on sports events were carried out: first, a research workshop was organised and all those sport event organisers without (or with poor) website information were invited to participate. The research 
DRUŠ. ISTRAŽ. ZAGREB GOD. 26 (2017), BR. 4, STR. 561-581

PERIĆ, M., ČUIĆ TANKO VIĆ, A., ĐURKIN, J.: ROLE OF BRAND.. workshop gathered 30 stakeholders (six local tourist board directors, seven presidents of local sports associations, and 17 public and civil sector representatives linked to Gorski Kotar sport life). Second, in-person and telephone interviews were conducted with 20 other important stakeholders who did not participate at the workshop (three local tourist board directors, 12 presidents of local sports associations, and five public and civil sector representatives). The main topic of both the workshop and interviews was identifying sports tourism events and determining their main characteristics, the approximate number of active participants and spectators, additional services provided, etc. Stakeholders were explicitly asked to list three main features of the sports events they organise (each organiser individually). In order not to affect the stakeholders, no prior ideas/solutions related to events features were anticipated or suggested. The final analysis included 81 small-scale sports events in the Gorski Kotar area, of which 57 and 24 are summer and winter events, respectively. The great majority of events are held outdoors (75), and only six are held indoors.

The second step of the methodology involved the implementation of grounded theory in analysing identified key characteristics of each event (three per event) and transforming them into brand personality traits. The methodology of Aaker (1997) was used to code "raw" characteristics to the personality traits, in particular her five dimensions and the set of personality traits norms provided in the brand personality scale (Aaker, 1997, p. 354). This methodology was selected due to its wide usage and important influence in the field of branding (as elaborated in the Literature review section). Some of the characteristics were repeating for different events, so the final result was a total of 101 personality traits out of 243 characteristics. In order to maintain the informational value of gathered event characteristics, we grouped only extremely similar characteristics (e.g. "technology" and "technology-oriented"). Matches between the events' characteristics and personality traits could not always be found immediately. The authors conducted parallel and independent coding, and differences between the matches in the coding process were then discussed and resolved by the opinion of the third author.

Table 1 presents the event characteristics associated to personality traits set by Aaker (1997), together with the frequencies of the facet names summarised. By implementing Aaker's methodology (Traits-Facet-Factor approach) and her framework of five dimensions for studying each brand personality, the following results were obtained. 
$\rightarrow$ TABLE 1

Brand personality profile of Gorski Kotar sports events

\begin{tabular}{lrll}
$\begin{array}{l}\text { Event } \\
\text { characteristics }\end{array}$ & Frequency & Facet Name & Factor Name \\
\hline Socialising & 19 & Down-to-earth (40) & SINCERITY (75) \\
Family-oriented & 10 & & \\
Recreational & 7 & & \\
Traditional & 3 & \\
Small-town & 1 & \\
Fun & 14 & Cheerful (27) & \\
Party-oriented & 5 & \\
Enjoyment & 3 & \\
Fun atmosphere & 2 & \\
Sentimental & 2 & \\
Enthusiastic & 1 & \\
Original & 8 & Original (8) & \\
& & Honest (0) &
\end{tabular}

Leisurely

Patience

Relaxation

Cool

Serious

Peaceful

Youthful

Spirited

Calm

Quiet

Young people

Adrenalin

Exciting

Adventure

Vibrant

Taking responsibility

Trendy

Well-known

Sensational

Imaginative

Dreamy

Innovative

Unique

Different

Alternative

Mysterious

Spiritual

Modern

Intuitive
Spirited (24)

EXCITEMENT (55)

Challenging,

\begin{tabular}{llll} 
extreme challenge & 7 & Outdoorsy (11) & RUGGEDNESS (45) \\
Active & 2 & \\
Masculine & 1 & \\
Not for everyone & 1 & \\
Competitive & 8 & Tough (34) \\
Rivalry & 8 & & \\
\hline
\end{tabular}


○ TABLE 1

(Continued)

572

\begin{tabular}{|c|c|c|c|}
\hline $\begin{array}{l}\text { Event } \\
\text { characteristics }\end{array}$ & & Facet Name & Factor Name \\
\hline Tough & 4 & & \\
\hline Dynamic & 3 & & \\
\hline Dangerous & 2 & & \\
\hline Speed & 2 & & \\
\hline Energetic & 2 & & \\
\hline Thrilling & 1 & & \\
\hline Fight & 1 & & \\
\hline Demanding & 1 & & \\
\hline Excessive & 1 & & \\
\hline Passionate & 1 & & \\
\hline Enjoying nature & 7 & Nature-oriented (22) & NATURE (34) \\
\hline Nature & 6 & & \\
\hline Beautiful surroundings & 3 & & \\
\hline Attractive ("white") scenery & 2 & & \\
\hline Enjoying green/nature & 2 & & \\
\hline Attractive scenery & 1 & & \\
\hline Many colours & 1 & & \\
\hline Respecting nature & 3 & Ecologically aware (6) & \\
\hline Ecology & 1 & & \\
\hline Enjoying clear water & 1 & & \\
\hline Fresh air & 1 & & \\
\hline Become part of nature & 1 & Immersed in nature (6) & \\
\hline Feeling of freedom & 1 & & \\
\hline Healthy & 1 & & \\
\hline Overwhelmed & 1 & & \\
\hline Refreshing & 1 & & \\
\hline True nature & 1 & & \\
\hline Hard-working & 1 & Reliable (2) & COMPETENCE (25) \\
\hline Reliable & 1 & & \\
\hline Precision & 4 & Intelligent (23) & \\
\hline Great skill & 3 & & \\
\hline High concentration & 3 & & \\
\hline High cooperation & 3 & & \\
\hline Intelligent & 2 & & \\
\hline Skillful & 2 & & \\
\hline Technology, & & & \\
\hline technology-oriented & 2 & & \\
\hline Mental challenge & 1 & & \\
\hline Education & 1 & & \\
\hline Focused & 1 & & \\
\hline Versatile & 1 & & \\
\hline Sophisticated & 3 & Upper-class (7) & SOPHISTICATION (9) \\
\hline Upper-class & 1 & & \\
\hline Senior citizens & 1 & & \\
\hline Aesthetic & 2 & & \\
\hline Feminine & 1 & Charming (2) & \\
\hline Smooth & 1 & & \\
\hline
\end{tabular}


DRUŠ. ISTRAŽ. ZAGREB GOD. 26 (2017), BR. 4 STR. 561-581

PERIĆ, M., ČUIĆ TANKOVIĆ, A., ĐURKIN, J. ROLE OF BRAND...
The adjectives emerging from the qualitative research represent a total of 101 personality traits, 54 of which appeared only once, with "socialising" being the most common event characteristic (19). The personality traits of the multidimensional brand personality construct for all events are predominantly characterized as "down-to-earth" (40), and "cheerful" (27). The sports events, as pillars of the region's sports activities, are mostly focused on the creation of family-oriented socialising activities which produce fun and joy. On the other hand, due to the specificity of events included in this research which are mostly outdoor sports events, the connected personalities of "tough" (34) and "daring" (20) seem justifiable. The events were described as competitive (8), rivalry (8), adrenalin (8) and challenging (7) with tough and dynamic elements.

During the coding process, all authors noticed that many characteristics could not be matched with the personality traits foreseen by the framework. These 16 adjectives were separated and, due to their internal logical connection, categorised into the new dimension called Nature. The main facets associated with this dimension are nature-oriented, ecologically aware and immersed in nature. This intervention in the original Aaker framework is supported by the recent literature which stresses the importance of the awareness of environmental issues and green orientation in brand creation (Crockett, Wood, 2002; Peloza \& Shang, 2011) and event development (Collins \& Flynn, 2008; Đurkin, Dadić, \& Medarič, 2015). This new Nature group is best described by the "nature-oriented" facet, and the number and recurrence of these event characteristics illustrate the importance of enjoying (preserved) natural surroundings, where the aesthetic component of nature can enhance the complete visitor experience and nature immersion.

\section{DISCUSSION AND CONCLUSIONS}

This research emphasises that the emotional appeal in brand messages makes it easier for tourists and visitors to recognise a destination's offering and events. Despite being a less-developed and indistinctive tourist destination in Croatia, Gorski Kotar may have the impetus needed to bring about transformative tourism development based on existing small-scale sports events as the region's competitive and comparative advantages. Because of its fragmented but rich event offering which is not distinctive and is poorly visited, Gorski Kotar requires an umbrella brand. Results obtained through personality traits coding and analysis provide a useful basis for recommendations on an overall umbrella brand for all sports events in Gorski Kotar. The overall brand personality profile 
DRUŠ. ISTRAŽ. ZAGREB GOD. 26 (2017), BR. 4, STR. 561-58

PERIĆ, M., ČUIĆ TANKO VIĆ, A., ĐURKIN, J. ROLE OF BRAND.. can be projected as fun, socialising, tough and nature-oriented. These elements should be included when developing the umbrella brand architecture, in order to offer a comprehensive experience easily recognised by the client and the visitor. Endless green and white colours in combination with the blue of clear skies should be used in association with the unpolluted environment derived from the dimension of Nature. Together with energy, challenges and adrenaline derived from competitiveness in sports, emotions that are evoked should include simplicity, cheerfulness, friendship and joy. In this way, the umbrella brand brings together diverse dominant elements of sports events, unifying them into an easily recognised brand with a wide variety and large number of events capable of attracting visitors. Hence, the umbrella brand emerging from the dimensions of brand personality should be operationalised to facilitate the identification and continuity of the tourism offer through events. In this way it could become an important driving force in creating a tourism value chain in less-developed regions.

While umbrella brand creation can be seen as a way of boosting weak events, the events themselves must be perceived as having a reputation of quality and appeal in the field of interest (Wernerfelt, 1988; Erdem, 1998). Bringing an event under the wing of an umbrella name or brand is not an end in itself, because, according to Kapferer (2012), brands are created to generate added value for customers and visitors. In the case of Gorski Kotar and other similarly less-developed and indistinctive regions, the application of a flexible umbrella-type strategy is important. It is especially important to ensure freedom in identifying emerging personality traits, which do not necessarily have to be coherent with the image of the overall tourist destination but which should be focused on the target market.

Braun \& Zenker (2010) confirmed umbrella brand creation as the first stage in establishing mother and daughter brands. This research, however, had the challenging motivation of engaging in an inductive and reverse process. Such an approach has enabled the identification and proposal of a new dimension of brand personality (Nature), which could be used in future research and branding of outdoor sports events. It has also confirmed that Aaker's (1997) framework of brand personality attributes is a robust and justified method of gathering key determinants and identifying brands.

In terms of implications for practitioners, the development and implementation of an umbrella brand requires a new level of mutual cooperation among event organisers, together with long-term planning of promotional and other activities, in order to maximise the benefits of common brand 
DRUŠ. ISTRAŽ. ZAGREB GOD. 26 (2017), BR. 4 STR. 561-581

PERIĆ, M., ČUIĆ TANKOVIĆ, A., ĐURKIN, J. ROLE OF BRAND... strategy and to reach specific target groups. Achieving a synergic effect from new management and marketing strategies is a special challenge, as well as being an inevitable precondition to the successful tourism development of less-distinctive regions.

This study presents an input of brand factors and dimensions for small-scale sports events that, in the right combination and weight, can result in a distinctive and creative umbrella brand. This brand relies on the creativity and communication ability of each brand manager. Cooperation in branding different small-scale events under a unified and distinctive umbrella brand could significantly increase overall tourism income (through larger participant and spectator numbers), without the need for excessive investment requirements.

\section{LIMITATIONS AND FURTHER RESEARCH}

The creation of an emerging umbrella brand derived from the brand personality dimensions can be useful in understanding the complexity of the tourism destination. Because it has symbolic values and is easy to recognise, the brand helps to unify the tourism offering. However, additional (quantitative as well as qualitative) studies are needed to determine the reliability and validity of the proposed new dimension (Nature), with emphasis on its extension to other facets, depending on the type of events analysed. Contextual restraints of region, events and authors themselves need to be taken into consideration in any future attempts to generalise the results of this research. Also, the fact that part of the characteristics used for analysis were taken from websites, while others were directly gathered from organisers (via the workshop and interviews) has to be taken into consideration. Without disregarding the fact that the case study method bears certain limitations in terms of replication of research results, Gorski Kotar could be an example for future comparison with research results in similar less-developed regions possessing natural beauties and various offerings of small-scale sports events. Some of the new lines of research arising from this paper include the possibility of bringing together under an umbrella brand sports events from different regions or creating a comparative study on brand personality profiles of small-scale sports events in several regions of "new states". Furthermore, even though this paper proposes umbrella brand elements based on the personality brand profile of various sports events, future research could use the same approach in assessing existing music or gastro events with the purpose of making further theoretical contributions as well as tangible recommendations in favour of future tourism development. 


\section{FUNDING ACKNOWLEDGEMENTS}

This work was supported by the Croatian Science Foundation [grant number UIP-2014-09-1214].

\section{REFERENCES}

Aaker, D. A. (1996). Measuring brand equity across products and markets. California Management Review, 38(3), 102-120. https://doi.org/10. 2307/41165845

Aaker, J. L. (1997). Dimensions of brand personality. Journal of Marketing Research, 34(3), 347-356. https://doi.org/10.2307/3151897

Aaker, J. L., Benet-Martinez, V., \& Garolera, J. (2001). Consumption symbols as carriers of culture: A study of Japanese and Spanish brand personality constructs. Journal of Personality and Social Psychology, 81(3), 492-508. https://doi.org/10.1037/0022-3514.81.3.492

Azoulay, A., \& Kapferer, J. N. (2003). Do brand personality scales really measure brand personality? Journal of Brand Management, 11(2), 143-155. https://doi.org/10.1057/palgrave.bm.2540162

Balachander, S., \& Ghose, S. (2003). Reciprocal spillover effects: A strategic benefit of brand extensions. Journal of Marketing, 67(1), 4-13. https://doi.org/10.1509/jmkg.67.1.4.18594

Bartoluci, M. (1995). Razvitak sportsko-rekreacijskog turizma u Hrvatskoj [Development of sports-recreational tourism in Croatia]. Acta-Turistica, 7(2), 137-157.

Bergh, B. G. V., \& Katz, H. E. (1999). Advertising principles: Choice, challenge, change. Lincolnwood, IL: NTC/Contemporary Publishing Group.

Braun, E., \& Zenker, S. (2010). Towards an integrated approach for place brand management. In 50th European Regional Science Association Congress, Jönköping, Sweden, 19th - 23rd August, 2010 (pp. 19-23).

Braunstein, J. R., \& Ross, S. D. (2010). Brand personality in sport: Dimension analysis and general scale development. Sport Marketing Quarterly, 19(1), 8-16.

British Tourist Authority (1981). Tourism in the UK - the broad perspective. London: BTA.

Buhalis, D., \& Laws, E. (2001). Tourism distribution channels: Patterns, practices and challenges. London: Thomson.

Buning, R. J., \& Gibson, H. (2015). The evolution of active-sport-event travel careers. Journal of Sport Management, 29(5), 555-569. https://doi.org/10.1123/jsm.2014-0215

Cabral, L. M. B. (2009). Umbrella branding with imperfect observability and moral hazard. International Journal of Industrial Organization, 27(2), 206-213. https://doi.org/10.1016/j.ijindorg.2008.07.002

Carlson, B. D., \& Donavan, D. T. (2013). Human brands in sport: Athlete brand personality and identification. Journal of Sport Management, 27(3), 193-206. https://doi.org/10.1123/jsm.27.3.193

Chalip, L. (2004). Beyond impact: A general model for sport event leverage. In B. W. Ritchie \& D. Adair (Eds.), Sport tourism: Interrelationships, impacts and issues (pp. 226-252). Clevedon: Channel View Publications. 
DRUŠ. ISTRAŽ. ZAGREB GOD. 26 (2017), BR. 4 STR. 561-581

PERIĆ, M., ČUIĆ TANKOVIĆ, A., ĐURKIN, J. ROLE OF BRAND...
Cheung, S. Y., Mak, J. Y., \& Dixon, A. W. (2016). Elite active sport tourists: Economic impacts and perceptions of destination image. Event Management, 20(1), 99-108. https://doi.org/10.3727/152599516X1 4538326025198

Cho, H., Ramshaw, G., \& Norman, W. C. (2014). A conceptual model for nostalgia in the context of sport tourism: Re-classifying the sporting past. Journal of Sport $\mathcal{E}$ Tourism, 19(2), 145-167. https://doi.org/ 10.1080/14775085.2015.1033444

Collins, A., \& Flynn, A. (2008). Measuring the environmental sustainability of a major sporting event: A case study of the FA Cup Final. Tourism Economics, 14(4), 751-768. https://doi.org/10.5367/0000000087 86440120

Crockett, S. R., \& Wood, L. J. (2002). Brand Western Australia: 'Holidays of an entirely different nature'. In N. Morgan, A. Pritchard, \& R. Pride (Eds). Destination branding: Creating the unique destination proposition (pp. 124-147). Oxford: Butterworths.

Čáslavová, E., \& Petráčková, J. (2011). The brand personality of large sport events. Kineziologija, 43(1), 91-106.

De Chernatony, L. (2009). Towards the holy grail of defining 'brand'. Marketing Theory, 9(1), 101-105. https://doi.org/10.1177/14705931081 00063

De Knop, P., \& Van Hoecke, J. (2003). The place of sport in the battle for the tourist: A figurational perspective of the development of sport tourism. Kinesiology, 35(1), 59-69.

Dixon, A. W., Henry, M., \& Martinez, J. M. (2013). Assessing the economic impact of sport tourists' expenditures related to a university's baseball season attendance. Journal of Issues in Intercollegiate Athletics, $6,96-113$

Downward, P. (2005). Critical (realist) reflection on policy and management research in sport, tourism and sports tourism. European Sports Management Quarterly, 5(3), 302-322. https://doi.org/10.1080/ 16184740500190702

Đurkin, J., Dadić, L., \& Medarič, Z. (2015). Useful information for zero waste event and festival management. In M. Perić \& M. Krstinić Nižić (Eds.), Zero Waste Guidelines for Events and Festivals (pp. 91-101). Opatija and Portorož: University of Rijeka, Faculty of Tourism and Hospitality Management and University of Primorska, Faculty of Tourism Studies.

Erdem, T. (1998). An empirical analysis of umbrella branding. Journal of Marketing Research, 35(3), 339-351. https://doi.org/10.2307/3152032

FTHM - Fakultet za menadžment u turizmu i ugostiteljstvu (2012). Izmjene i dopune Glavnog plana razvoja turizma Primorsko-goranske županije [Amendments to Master plan of tourism development of Primorsko Goranska County]. Opatija: Fakultet za menadžment u turizmu i ugostiteljstvu.

FTHM - Fakultet za menadžment u turizmu i ugostiteljstvu Opatija (2013). Gorski kotar - Zeleno srce Hrvatske; Polazne osnove dugoročnog razvoja turizma destinacije Gorski kotar [Gorski Kotar - Green heart of Croatia; Starting points for long-term sustainable development of tourism of Gorski Kotar]. Opatija: Fakultet za menadžment u turizmu i ugostiteljstvu. 
DRUŠ. ISTRAŽ. ZAGREB GOD. 26 (2017), BR. 4, STR. 561-58

PERIĆ, M., ČUIĆ TANKOVIĆ, A., ĐURKIN, J. ROLE OF BRAND..
Gammon, S., \& Robinson, T. (1997). Sport and tourism: A conceptual framework. Journal of Sport Tourism, 4(3), 11-18. https://doi.org/10. 1080/10295399708718632

Getz, D. (2008). Event tourism: Definition, evolution, and research. Tourism Management, 29(3), 403-428. https://doi.org/10.1016/j.tourman. 2007.07.017

Gibson, H. J., Kaplanidou, K., \& Kang, S. J. (2012). Small-scale event sport tourism: A case study in sustainable tourism. Sport Management Review, 15(2), 160-170. https://doi.org/10.1016/j.smr.2011.08.013

Gibson, H. J., Willming, C., \& Holdnak, A. (2003). Small-scale event sport tourism: Fans as tourists. Tourism Management, 24(2), 181-190. https://doi.org/10.1016/S0261-5177(02)00058-4

Gibson, H. J. (1998). Sport tourism: A critical analysis of research. Sport Management Review, 1(1), 45-76. https://doi.org/10.1016/S14413523(98)70099-3

Glyptis, S. A. (1982). Sport and tourism in Western Europe. London: British Travel Education Trust.

Government of the Republic of Croatia (2013). Tourism development strategy of the Republic of Croatia until 2020.

Gozalova, M., Shchikanov, A., Vernigor, A., \& Bagdasarian, V. (2014). Sport tourism. Polish Journal of Sport Tourism, 21(2), 92-96. https://doi. org/10.2478/pjst-2014-0009

Hallmann, K., \& Breuer, C. (2011). Images of rural destinations hosting small-scale sport events. International Journal of Event and Festival Management, 2(3), 218-244. https://doi.org/10.1108/17582951111170290

Heere, B. (2010). A new approach to measure perceived brand personality associations among consumers. Sport Marketing Quarterly, 19(1), 17-24.

Higham, J. (1999). Commentary - Sport as an avenue of tourism development: An analysis of the positive and negative impacts of sport tourism. Current Issues in Tourism, 2(1), 82-90. https://doi.org/ 10.1080/13683509908667845

Hoeffler, S., \& Keller, K. L. (2003). The marketing advantages of strong brands. Journal of Brand Management, 10(6), 421-445. https://doi.org/ 10.1057/palgrave.bm.2540139

Hosany, S., Ekinci, Y., \& Uysal, M. (2006). Destination image and destination personality: An application of branding theories to tourism places. Journal of Business Research, 59(5), 638-642. https://doi.org/ 10.1016/j.jbusres.2006.01.001

http://www.gorskikotar.hr

Jago, L., Chalip, L., Brown, G., Mules, T., \& Ali, S. (2003). Building events into destination branding: Insights from experts. Event $M a-$ nagement, 8(1), 3-14. https://doi.org/10.3727/152599503108751658

Kapferer, J. N. (2012). The new strategic brand management: Advanced insights and strategic thinking. London: Kogan Page Publishers.

Keller, K. L. (1993). Conceptualizing, measuring, and managing customer-based brand equity. Journal of Marketing, 57(1), 1-22. https://doi. org/10.2307/1252054 
DRUŠ. ISTRAŽ. ZAGREB GOD. 26 (2017), BR. 4, STR. 561-581

PERIĆ, M., ČUIĆ TANKOVIĆ, A., ĐURKIN, J. ROLE OF BRAND...
Keller, K. L. (2003). Brand synthesis: The multidimensionality of brand knowledge. Journal of Consumer Research, 29(4), 595-600. https://doi. org/10.1086/346254

Khodr, H. (2012). Exploring the driving factors behind the event strategy in Qatar: A case study of the 15th Asian Games. International Journal of Event and Festival Management, 3(1), 81-100. https://doi.org/ 10.1108/17582951211210951

Kotler, P., \& Keller, K. L. (2006). Marketing management (12th ed.). Upper Saddle River, NJ: Pearson Prentice Hall

Lee, H. S., \& Cho, C. H. (2009). The matching effect of brand and sporting event personality: Sponsorship implications. Journal of Sport Management, 23(1), 41-64. https://doi.org/10.1123/jsm.23.1.41

Liu, X., \& Hu, M. Y. (2011). Umbrella brand price premiums: Effects of compatibility, similarity, and portfolio size. Journal of Product $\mathcal{E}$ Brand Management, 20(1), 58-64. https://doi.org/10.1108/106104211111 08021

Lundmark, L., \& Muller, D. K. (2010). The supply of nature-based tourism activities in Sweden. Tourism, 58(4), 379-393.

Ministry of Tourism; Ministarstvo turizma Republike Hrvatske (2015). Turizam u brojkama 2014 [Tourism in figures 2014]. Ministarstvo turizma. Available at http://www.mint.hr/UserDocsImages/150701 Turizam014.pdf

Ministry of Tourism; Ministarstvo turizma Republike Hrvatske (2016a). HNB: Prihodi od turizma u 2015. godini ostvarili rast od 7,6 posto [CNB: Tourism revenue increased in 2015 by 7,6\%]. Ministarstvo turizma. Available at http://www.mint.hr/default.aspx?id=32920

Ministry of Tourism; Ministarstvo turizma Republike Hrvatske (2016b). Turistički promet od siječnja do prosinca 2015. godine [Tourism activity from January to December 2015]. Ministarstvo turizma. Available at http://www.mint.hr/UserDocsImages/160219_tpromet015.pdf Morgan, N., Pritchard, A., \& Pride, R. (2004). Destination branding: Creating the unique destination proposition. Oxford: Butterworths.

Murphy, L., Moscardo, G., \& Benckendorff, P. (2007). Using brand personality to differentiate regional tourism destinations. Journal of Travel Research, 46(1), 5-14. https://doi.org/10.1177/0047287507302371

O'Brien, D. (2007). Points of leverage: Maximizing host community benefit from a regional surfing festival. European Sport Management Quarterly, 7(2), 141-165. https://doi.org/10.1080/16184740701353315

Parent, M. M., \& Séguin, B. (2008). Toward a model of brand creation for international large-scale events: The impact of leadership, context, and nature of the event. Journal of Sport Management, 22(5), 526-549. https://doi.org/10.1123/jsm.22.5.526

Parent, M. M., Eskerud, L., \& Hanstad, D. V. (2012). Brand creation in international recurring sports events. Sport Management Review, 15(2), 145-159. https://doi.org/10.1016/j.smr.2011.08.005

Peloza, J., \& Shang, J. (2011). How can corporate social responsibility activities create value for stakeholders? A systematic review. Journal of the Academy of Marketing Science, 39(1), 117-135. https://doi.org/ 10.1007/s11747-010-0213-6 
DRUŠ. ISTRAŽ. ZAGREB GOD. 26 (2017), BR. 4, STR. 561-58

PERIĆ, M., ČUIĆ TANKO VIĆ, A., ĐURKIN, J. ROLE OF BRAND..
Pereira, E. C. S., Mascarenhas, M. V. M., Flores, A. J. G., \& Pires, G. M. V. S. (2015). Nautical small-scale sports events portfolio: A strategic leveraging approach. European Sport Management Quarterly, 15 (1), 27-47. https://doi.org/10.1080/16184742.2015.1007883

Perić, M. (2015). Managing sports experiences in the context of tourism. UTMS Journal of Economics, 6 (1), 85-97.

Perić, M., Škorić, S., \& Jurčević, V. (2016). Sport tourism supply in Gorski Kotar (Croatia) - Analysis and possible recommendations for providers. Acta Turistica, 28(1), 49-71.

Petty, R. C., \& Krosnick, J. A. (1994). Attitude strength: Antecedents and consequences. Hillsdale (NJ): Lawrence Erlbaum and Associates.

Ratten, V. (2011). Practical implications and future research directions for international sports management. Thunderbird International Business Review, 53(6), 763-770. https://doi.org/10.1002/tie.20451

Roche, S., Spake, D. F., \& Joseph, M. (2013). A model of sporting event tourism as economic development. Sport, Business and Management: An International Journal, 3(2), 147-157. https://doi.org/10.1108/20426 781311325078

Singh, D. (2013). The brand personality component of brand goodwill: Some antecedents and consequences. In Brand Equity \& Advertising: Advertising's Role in Building Strong Brands (pp. 83-96).

Smith, A. (2006). Tourists' consumption and interpretation of sport event imagery. Journal of Sport $\mathcal{E}$ Tourism, 11(1), 77-100. https://doi. org/10.1080/14775080600985382

Standeven, J., \& Tomlinson, A. (1994). Sport and tourism in South East England: A preliminary assessment. London: SECSR.

Supphellen, M., \& Grønhaug, K. (2003). Building foreign brand personalities in Russia: The moderating effect of consumer ethnocentrism. International Journal of Advertising, 22(2), 203-226. https://doi. org/10.1080/02650487.2003.11072849

Ulrich, D., \& Smallwood, N. (2007). Leadership brand: Developing customer-focused leaders to drive performance and build lasting value. Boston, MA: Harvard Business School Press.

Usakli, A., \& Baloglu, S. (2011). Brand personality of tourist destinations: An application of self-congruity theory. Tourism Management, 32(1), 114-127. https://doi.org/10.1016/j.tourman.2010.06.006

Weed, M. (2009). Progress in sports tourism research? A meta-review and exploration of futures. Tourism Management, 30(5), 615-628. https:/doi. org/10.1016/j.tourman.2009.02.002

Weed, M., \& Bull, C. (2009). Sport tourism: Participants, policy and providers. Second edition. Oxford: Elsevier Butterworth Heinemann.

Wernerfelt, B. (1988). Umbrella branding as a signal of new product quality: An example of signalling by posting a bond. The RAND Journal of Economics, 19(3), 458-466. Available at http://www.jstor.org/ stable/2555667?seq=1\#page_scan_tab_contents

World Tourism Organisation (2010). Yearbook of tourism statistics. Madrid: WTO.

Ziakas, V. (2014). Event portfolio planning and management: A holistic approach. London: Routledge. 
DRUŠ. ISTRAŽ. ZAGREB GOD. 26 (2017), BR. 4 STR. 561-581

PERIĆ, M., ČUIĆ TANKOVIĆ, A., ĐURKIN, J. ROLE OF BRAND...

\section{Uloga karakteristika osobnosti brenda u stvaranju krovnoga brenda za sportske događaje malih razmjera: primier Gorskoga kotara u Hrvatskoj}

Marko PERIĆ, Ana ČUIĆ TANKOVIĆ, Jelena ĐURKIN

Fakultet za menadžment u turizmu i ugostiteljstvu, Opatija

Važnost i pozitivni učinci sportskih događaja malih razmjera (eng. small-scale sports events) za turizam regija $u$ kojima se odvijaju jesu relativno dobro istražena pojava, no mogućnosti brendiranja tih događaja specifičnim zajedničkim nazivnikom nisu do kraja istražene. Ovaj članak koristi se konceptima osobnosti brenda (eng. brand personality) i krovnoga brenda (eng. umbrella brand) u svrhu davanja preporuka za analizu i promociju malih sportskih događaja. Kao područje istraživanja odabrana je Hrvatska, preciznije Gorski kotar, kao jedna od manje razvijenih regija. Istraživanjem su obuhvaćeni sportski događaji malih razmjera koji se odvijaju na tom području, s konačnim ciljem stvaranja generalnih preporuka za zajednički krovni brend koji bi se temeljio na analizi zajedničkih svojstava svih istraživanih događaja. Primjenom metoda istraživanja za stolom, radionica te intervjua s organizatorima događaja određene su po tri karakteristike za svaki od 81 promatranoga sportskog događaja. Istraživački okvir sastavlien od 5 dimenzija osobnosti brenda (Aaker, 1997) uzet je za kodiranje karakteristika u svojstva i njihova kasnijega povezivanja s pripadajućim dimenzijama. Stvoren je ukupni profil osobnosti brenda svih događaja, a rezultati su pokazali potrebu dodavanja nove dimenzije pod nazivom priroda (usmieren prema prirodi) u postojeći okvir.

Ključne riječi: osobnost brenda, krovni brend, sportski događaji malih razmiera, turizam

\section{(c) (i) ()}

Međunarodna licenca / International License:

Creative Commons Attribution-NonCommercial-NoDerivatives 4.0. 